\title{
Reading the New Standard ISA700
}

\author{
Daniel Botez, University "Vasile Alecsandri "Bacau, Romania
}

\begin{abstract}
:
Review of permanent professional standards is a requirement for professional bodies of professional accountants, resulting in broader processes of globalization and harmonization. A set of revised standards on financial audit engagement was published by IFAC in April 2009. International Standard on Auditing (ISA) 700 "Forming an opinion and reporting on financial statements" is one of them.

This standard deals with the auditor's responsibility to form an opinion on the financial statements and determine the form and content of the auditor's report issued following an audit of financial statements. Even if you do not have major changes, the revised standard contains several provisions that emphasize the important role of the auditor's report and more specifically defines its responsibility.
\end{abstract}

\section{Keywords:}

International Auditing Standards, audit report ISA700

JEL Code : M42

\section{Introduction}

In April 2009, IFAC (International Federation of Professional Accountants) published a set of International Standards on Auditing (ISAs) revised. It's about standards relating to financial statement audit engagement.

One of the main points of the revision process is the formulation of these standards by reference to a standard structure which includes the following:

- Introduction - it is presented the scope of standard and revealing at the same time, the need for it, and on the standard takes effect;

- Objective - Auditor general objective is to obtain sufficient appropriate evidence about the scope of the standard;

- Definitions - they have to assign appropriate meanings of terms used, in application of International Standards

- Audit Requirements - include rule, audit procedures the auditor should apply to achieve the objective standard, and how to issue and reporting their findings;

- Application and other explanatory material - the auditing procedures and to issue findings and are detailed for the purposes of reporting to the auditor of additional references and the insertion of annexes, where appropriate, containing reporting templates and other information.

One of the key standards, which sets the reference coordinates reporting of audit opinion mission is International Standard on Auditing 700. Called up in 2009 "Independent Auditor's Report on a full set of general purpose financial statements, the revised standard is called "forming an opinion and reporting on financial statements".

Having knowledge of its provisions, the auditor found some new elements which establish a more rigorous delineation of its area.

The purpose of this study is to highlight these new elements contained in the revised standard. 


\section{Why a new standard 700?}

First, there is talk of forming an opinion on the auditor's responsibility. The auditor's report is the interface through which the conclusions of its work are made available to users.

Opinions stated in the report summarizes, on a qualitative level, all personal valences from the auditor's professionalism, experience, ability to collect and interpret evidence.

Furthermore, the report needs to show consistency, qualitative aspect with reference to auditing standards global markets induces credibility, and helps users understand the report and identify unusual circumstances.

New standard form of auditor's objectives emphasizes the audit report. They are:

a) to form an opinion on the financial statements based on an assessment of the conclusions drawn from audit evidence obtained, and

b) clearly express an opinion by the inclusion in the report to describe the basis of this opinion.

One of the new issues presented relate to the identification of the financial reporting framework. The previous version of the standard reference was "applicable financial framework" or "acceptable financial framework, both leading to the requirement of fair presentation. The revised version, the appearance varies in terms of conceptual definitions are included to guide the identification of this framework.

Thus, the applicable financial reporting is defined as the financial reporting framework adopted by management and where appropriate, by those charged with governance in the financial statements, which is acceptable in terms of the nature and objectives of the entity financial statements, or required by law or regulation.

Further defined two references to financial reporting framework.

The term "fair presentation framework is used to refer to a financial reporting framework that requires compliance with the framework and:

(1) explicitly or implicitly recognizes that to achieve a fair presentation of financial statements would might be necessary leadership to provide presentations which exceed those required specifically by the reporting, or

(2) explicitly acknowledged that it might be necessary for management to deviate from a provision of the framework General to obtain a fair presentation of financial statements. Such deviations are expected to be needed only in extremely rare situations.

The term "compliance framework" is used to refer to a financial reporting framework that requires compliance with the compliance framework, but no recognition of (1) and (2) above. The formation of opinions on financial statements, the auditor should determine whether obtaining a reasonable assurance whether the financial statements of material misstatement due to fraud or error.

To obtain reasonable assurance, whether the auditor has obtained sufficient evidence and relevant. This relates to the requirements of ISA 330 "auditor response to assessed risks". A new aspect concerns the auditor's conclusions about the significance of identified misstatements. These conclusions relate to the requirements of ISA 450 "Misstatements identified during the audit assessment". Is a new standard dealing with the auditor's responsibility to evaluate the effect of identified misstatements on the audit and of uncorrected misstatements on the financial statements.

The auditor also should assess whether the financial statements are prepared, in all material respects, in accordance with the applicable financial reporting. Same evaluation includes consideration of qualitative aspects of the entity's accounting practices, including evidence of a preconceived attitudes in management's reasoning.

Furthermore, the auditor should evaluate whether, in view of the applicable financial reporting framework:

Financial statements suitable accounting policies selected and applied; 
Accounting policies selected and applied are consistent with the applicable financial reporting and appropriate;

$\square$ Accounting estimates issued management are reasonable

$\square$ The information presented in financial statements is relevant, reliable, comparable and understandable;

$\square$ Financial statements revealing target adequate to enable users to understand the effect of significant transactions and events on the information provided in the financial statements and

\section{$\square \quad$ Terminology used financial statements, including the title of each component is appropriate.}

Text in bold above represent assessment requirements introduced by the revised standard. In principle, financial reporting frameworks that present financial statements are prepared and presented in public are fair presentation frameworks. In these circumstances, the auditor requested evaluations should include assessing whether the financial statements contain a fair review, evaluation includes consideration of:

$\square$ overall presentation, structure and content of financial statements;

$\square$ whether the financial statements, including notes, represent transactions and events in a manner that ensures fair presentation.

As a direct consequence of applying International Standards on Auditing, the auditor should express an opinion unconditional (unchanged, without reservation) when it concluded that financial statements are prepared, in material respects, in accordance with the applicable financial reporting.

On the other hand, if the auditor concludes that based on evidence gathered, the financial statements present misstatement or is unable to obtain sufficient appropriate evidence, it changes the view in accordance with ISA 705 "Modifications of the independent auditor's opinion report.

If a financial statement prepared in accordance with a fair presentation framework does not achieve a fair presentation, the auditor should discuss with the management entity and, according to the requirements of the applicable and how the issue is resolved, whether it is necessary to change the view.

If financial statements prepared in accordance with a fair presentation framework does not achieve a fair presentation, the auditor should discuss with the management entity and, according to the requirements of the applicable and how the issue is resolved, whether it is necessary to change the view.

Regarding components auditor's report, there is no new aspects. It must contain at least the following:

$\square$ Title - auditor's report should have a title which clearly indicates that an independent auditor's report

$\square$ Destination - the report be addressed in accordance with the circumstances of the engagement

$\square$ Introductory paragraph - which include:

- identification entity whose financial statements are audited statement that

- audited financial statements are the identification of each component of the reference set of financial statements in summary

- significant accounting policies and other explanatory information

- the date and period of each component of the financial statements

$\square$ Management responsibility, describing the responsibilities of that organization which is responsible for preparing financial statements. The auditor's report must cover not management, but must use the most appropriate term. The report must describe the management responsibility for financial statements, including responsibility for drawing them in accordance with the applicable financial reporting and internal control organization necessary to ensure that financial statements are free of material misstatement due to fraud or error. 
Responsibility Auditor - the report should state that the auditor's responsibility is to issue an opinion on the financial statements based on audit, it was carried out in accordance with ISAs and explain that these standards require the auditor comply with ethical requirements, and and plan and perform the audit to obtain reasonable assurance that financial statements are free of material misstatement. The report should indicate whether the auditor believes that the evidence obtained is sufficient and adequate to provide a basis for opinion.

The auditor's opinion - an opinion you express unconditional (unchanged, no reservations) on the financial statements prepared in accordance with a framework for fair presentation, the view should use one of the forms:

$\checkmark$ financial statements present fairly (fairly) in all material respects ........., under ...........( framework)

$\checkmark$ financial statements give (have) a fairly ............................ under (The) When expressing an unmodified opinion on financial statements prepared by reference to a framework of compliance, the auditor should express the view that financial statements were prepared in all material respects, in accordance with ....( The).

If this framework is IFRS or IPSAS, the auditor's opinion should identify the jurisdiction of origin of that frame.

$\square$ Other reporting responsibilities - whether auditor reporting responsibilities include other, additional responsibilities under the ISAs, it will include a separate section entitled "Report on other legal or regulatory requirements. If the report contains such a section, then report title will be "Report on Financial Statements.

$\square$ Signature of auditor - report must be signed

Data report - report not be dated before the date on which the auditor has obtained sufficient appropriate audit evidence to underpin the view, and all components of the financial statements have been prepared and those with recognized authority and assumed responsibility for those statements.

Address Auditor - the report must show the name of the location of the jurisdiction where the auditor practices.

It introduces provisions on auditor behavior then you must use a specific type of report. If the auditor is required by law or regulatory requirements specific to certain jurisdictions, to use a specific format of the report, the report may refer to ISAs only if it includes at least the elements described above.

If the auditor should apply the specific auditing standards other than ISAs, it may refer to ISAs in addition to national standards only if there is any conflict between the requirements of national standards and ISAs, which lead to the auditor to form a different opinion or not to include an emphasis paragraph if required by ISAs, and the auditor's report includes the minimum set of ISA elements 700. If additional information not required for financial reporting framework, are presented together with the audited financial statements, the auditor should identify where such information is clearly differentiated from the audited financial statements.

If they are not clearly differentiated, the auditor should request a change in how the additional information are unaudited. If management refuses, the auditor should explain in the report that the information is not audited.

\section{Conclusion}

The set of standards issued by IFAC in April 2009 set a reference date for financial statement audit engagement. In this reference, how the auditor shall provide reasonable information published stakeholder's entity is essential for understanding of these financial statements. ISA 700 contains references absolutely necessary for the auditor to successfully complete his professional approach. 


\section{Studies and Scientific Researches - Economic Edition, no. 15, 2010}

\section{Bibliography}

1. IFAC CAFR, Handbook of International Auditing Standards and Quality Control, Financial Audit 2009 Irecson Publishing, Bucharest, 2009

2. www.ifac.org/ISA 700 